\title{
Role of genetic resistance in managing ecosystems susceptible to white pine weevil ${ }^{1}$
}

\author{
by René I. Alfaro ${ }^{2}$
}

This paper describes the conditions that make stands of spruce (Picea spp. susceptible to attack by the white pine weevil, Pissodes strobi Peck, in British Columbia and discusses how host genetic resistance could be utilized to complement silvicultural tactics in the management of this pest.

Key words: Pissodes strobi, pest management, Picea spp., silviculture
Cet article décrit les conditions qui rendent les peuplements d'épinettes (Picea spp.) susceptibles d'être attaqués par le charançon du pin blanc, Pissodes strobi Peck, en ColombieBritannique et élabore comment la résistance génétique de l'hôte pourrait être utilisée pour compléter les tactiques sylvicoles utilisées dans la gestion des ce ravageur.

Mots clés: Pissodes strobi, gestion des ravageurs, Picea spp., sylviculture

\section{Introduction}

The white pine weevil, Pissodes strobi Peck, is an indigenous insect of North America, and can be found in most regions of Canada (Humble et al. 1994) and the United States. In British Columbia (BC) this insect has become a serious pest of reforestation, causing severe damage to young stands of Sitka spruce, Picea sitchensis (Bong) Carr., Engelmann spruce, Picea engelmannii Parry, white spruce, Picea glauca (Moench) Voss, and their hybrids, and occasionally to lodgepole pine, Pinus contorta Dougl. The hosts attacked in eastern North America include eastern white pine, Pinus strobus L., Jack pine, Pinus banksiana Lamb., Norway spruce, Picea abies (L.) Karst, Scots pine, Pinus sylvestris L., white spruce, and red spruce, Picea rubens Sarg.

Adult $P$. strobi overwinter in duff, usually near the tree from which they emerged in the previous fall. Early in the spring the weevils become active and can be seen feeding on the bark of branches and stem. Later, adults move to undamaged leaders of host trees where they mate and lay eggs below the apical bud, in feeding punctures which are then covered with a fecal plug. After hatching, the larvae orient downwards and consume the phloem. As their galleries merge, the larvae form the characteristic "feeding ring", in which they move downwards in synchrony, consuming all phloem, girdling and destroying the leader. Pupation takes place in chambers excavated in the xylem which are covered with wood fibers. New adults emerge from late July to September, feed for a while, and when temperatures drop and photoperiod shortens, move to the duff to hibernate (Silver 1968).

After a successful attack, a tree may take from one to several years to recover. In this process, branches from the uppermost whorl below the damaged terminal compete for dominance, and the tree remains for one or more years with multiple lead-

\footnotetext{
${ }^{1}$ Paper presented at the "Silvicultural Approaches to Integrated Insect Management" Workshop, Entomological Society of Canada Annual Meeting, 16-19, October 1994, Winnipeg, Manitoba.

${ }^{2}$ Pacific Forestry Centre, Canadian Forest Service, Victoria, British Columbia, Canada V8Z 1 M5.
}

ers. Depending on the number of internodes destroyed and the growth characteristics of the tree, a permanent stem defect could form at the point of injury (Alfaro 1989; Alfaro and Omule 1990). Losses in severely infested stands, due to reduced growth and defect can be as high as $40 \%$ of the stand volume (Alfaro 1992, 1994).

Understanding how weevil populations are held in check under natural conditions, and why outbreaks develop in plantations, is important for the development of silvicultural systems that are successful in reducing outbreak risk. This review examines the causes of outbreaks in natural stands and plantations, and discusses how host genetic resistance could be used along with silvicultural manipulation, to reduce stand susceptibility to weevil outbreaks.

Weevil populations are regulated by several factors (Alfaro 1994), with the most important being availability of oviposition sites (upright healthy leaders), larval food supply (leaders with thick phloem), climate (McMullen 1976) and vertebrate and invertebrate natural enemies (Alfaro et al. 1985). Although the weevil feeds throughout the main stem and branches, the niche for oviposition is exclusively the upright, year-old leader. Once a leader has been destroyed, the tree is usually not available for re-attack unless a new leader has formed. Re-attack of a leaderless tree has been reported (Cozens 1987), but it is uncommon. Therefore, the availability of oviposition sites is a major population regulation factor.

\section{The Need for Ecosystem Restoration and Management}

The widespread planting of single-species spruce stands in the 1960 s and 1970 s created optimal conditions for weevil development. Large plantations with vigorous regeneration provided an enormous supply of oviposition sites and food for the weevil. Also, in these open plantations, heat accumulation (McMullen 1976) was more than appropriate for weevil development. Under these conditions, population explosions or outbreaks developed. Outbreaks on monocultured Sitka spruce (Alfaro and Omule 1990) begin when plantations are about five years old. First, a few trees are attacked, then the population grows rapidly to rates of 30-50\% trees attacked per year (Fig. 


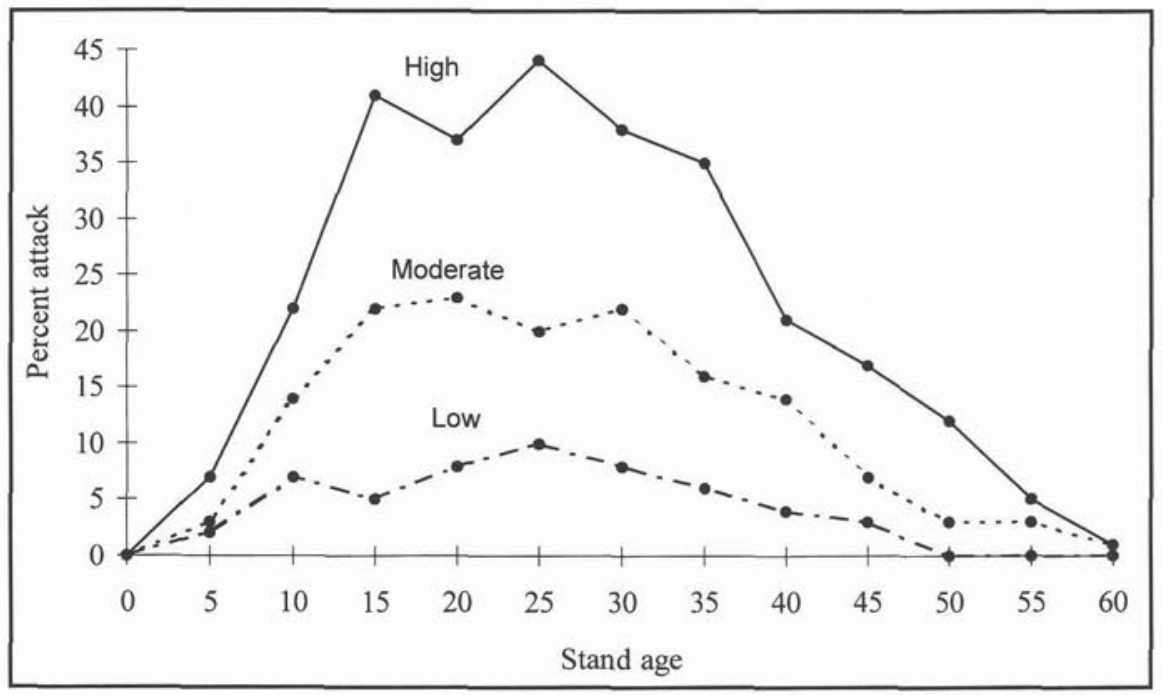

Fig. 1. Schematic representation of white pine weevil outbreaks on monocultures of Sitka spruce in stands located in high, moderate and low weevil hazard zones of British Columbia
1). The rapid infestation increase in this initial stage is due to the large proportion of trees available for attack, and to the fact that many attacks result in multiple leaders, increasing the number of oviposition sites and the supply of food for the larvae. After this initial period of invasion, the percentage of trees attacked each year stabilizes with annual fluctuations due to the variable effects of weather, natural enemies, larval crowding, and other mortality factors. This stability phase may last 10 to 20 years and is caused by a dynamic equilibrium between the weevil population and the supply of oviposition sites and larval food. The stability level is higher on good, warm sites, where vigorous growth ensures a rapid development of new leaders, than on poor, cool sites (Fig. 1). Gradually, this equilibrium gives way to a population decline phase, in which the rate of attack drops to less than $5 \%$ of the trees $\mathrm{yr}^{-1}$ by plantation age $30-40$ years. The reasons for the decline are probably multiple. By this age, the plantation has passed the stage of most vigorous growth and leader size declines, which results in a gradual reduction in larvae food supply and breeding substrate. Also, with the onset of canopy closure, there are changes in the stand microclimate (see below) which have a negative impact on weevil oviposition and survival.

\section{Lessons from Natural Stands}

Pissodes strobi is rare in natural, undisturbed stands. Here the weevil is found mostly in exposed regeneration occurring at stand edges or in openings, such as those created by the fall of older trees. Outbreaks develop where catastrophic events such as fire or wind storms create large patches of open-grown spruce regeneration. Studies on older stands located near Williams Lake indicate that weevil attacks in fire-regenerated white spruce were frequent between tree heights of 3 to $17 \mathrm{~m}$ (Fig. 2).

Natural stands have several characteristics which prevent outbreaks from occurring:

\section{(a) Shaded, Cool Habitats}

Climate and microclimate play a major regulatory role in the population dynamics of the white pine weevil. McMullen (1976) calculated that a minimum heat accumulation of 888 degreedays above 7.2 C was necessary for completion of weevil development in coastal Sitka spruce (785 degree-days for white spruce). Natural spruce stands (coast and interior) are shadier and cooler than plantations and have a microclimate less favourable for weevil development. Ongoing work by Taylor et al. (1996) on white spruce demonstrated that weevil damage decreases under canopies with increasing crown closure (shading) (Fig. 3). McLean $(1989,1994)$ found a similar reduction of weevil damage in Sitka spruce grown under red alder, Alnus rubra Bong. in BC. In eastern Canada, Wallace and Sullivan (1985) concluded that dense, shaded eastern white pine stands have conditions of temperature and humidity which are unfavourable for weevil feeding, oviposition and development.

\section{(b) Low Food Supply and Sub-optimal Oviposition Sites}

Spruce regeneration under shade grows slowly, producing thinner leaders which contain less food for the weevil larvae. Often these natural stands contain mixed species and a low host density $\mathrm{ha}^{-1}$, which further decreases availability of oviposition sites and larval food. In addition, observations in eastern white pine (Sullivan 1961) indicated that egg deposition on shaded leaders tended to occur in a diffused pattern rather than be concentrated in the upper sections of the leader as is more frequent on open grown trees. Concentrated egg deposition (mass attack) seems to be a requirement for successful leader colonization as the larvae need to aggregate and move downwards in synchrony, forming the feeding ring, in order to quickly overcome the tree defenses (Alfaro et al. 1996a). Solitary larva are more susceptible to pitch drowning.

\section{(c) Complex Trophic Webs}

A number of parasitoids (Alfaro et al. 1985) as well as vertebrate and invertebrate predators consume the various stages of $P$. strobi. However, this natural enemy complex is not effective in reducing weevil populations once they reach outbreak levels. Although untested, probably the parasitoid and predator complexes (e.g. ground carabid predators) are more diverse or more effective in natural stands than in plantations. Effectiveness of natural enemies could be higher in natural stands because the overall ecosystem complexity is much higher than in single-species plantations, and because the weevil populations are lower. Not only are the plant communities more diverse, but their structural complexity is much higher, as they form multilayered stands. Due to their sensitivity to habitat destruction (LaSalle and Gauld 1993), parasitic 


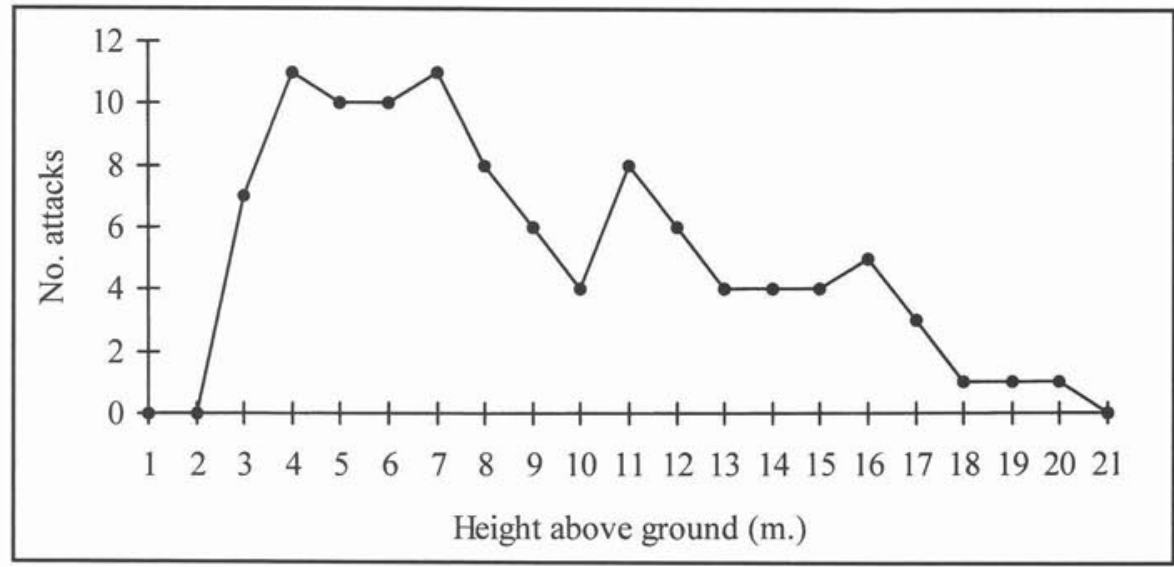

Fig. 2. Number of $P$. strobi attacks visible on stems of white spruce in a 60-year-old stand, tabulated by height above ground. The stand regenerated naturally after fire. Figure based on dissection of 41 trees.
Fig. 3. Percentage of interior spruce trees attacked by the white pine weevil when growing under increasing conditions of overstory crown cover. Class $1=$ open-grown tree; Class $8=100 \%$ overstory crown cover. Redrawn from Taylor et al. 1996.

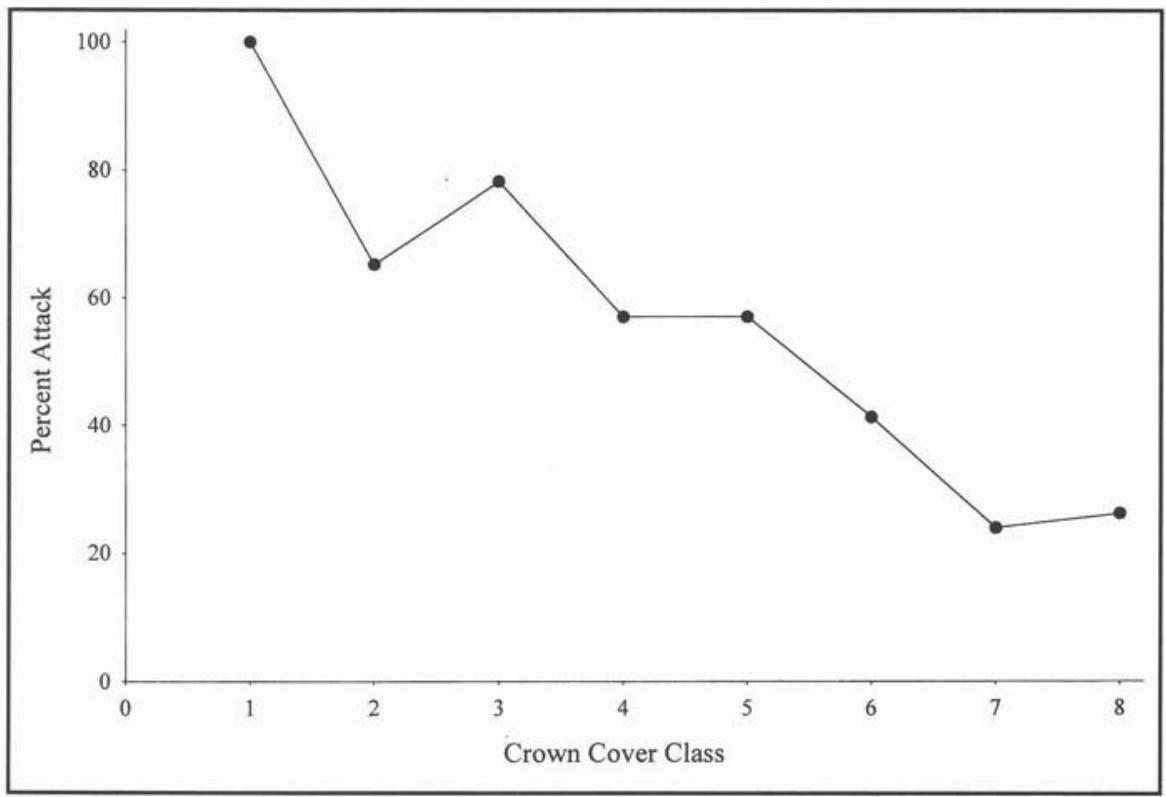

hymenoptera may be affected negatively in single-species plantations. In agroecosystems, natural enemy diversity is enhanced by crop diversity, abundance of ground cover, weeds and native vegetation adjacent to crops (Altieri 1994). Companion vegetation satisfies other needs of the parasitoid (shelter, food, water, pollen, alternate hosts). Interactions in the complex trophic web of natural stands probably suppress weevil populations, reducing the likelihood of weevil epidemics.

\section{Management of the White Pine Weevil}

An Integrated Pest Management System (IPM) has been proposed for $P$. strobi (Alfaro et al. 1995). This system relies on restoring ecosystem balance by reducing the conditions that lead to outbreak development. The system recommends tactics that diminish heat accumulation in the stand by encouraging growth of suitable non-host conifers as well as an overstory of deciduous species such as aspen or alder. These conditions render the stand cooler and shadier, reduce oviposition sites and food supply because trees produce short, thin leaders, and may create conditions which enhance natural ecemy populations. Reduction of stem defects by sanitation thinning and by planting at close spacing is also recommended.
Central to IPM is the continuous monitoring of weevil populations and forecasting of weevil impacts on forest productivity. This can be accomplished through a computerized decision support system, which helps to evaluate the need for, and the possible benefits of a given tactic.

\section{Adding Host Genetic Resistance to} Ecosystems Susceptible to Weevil Infestations

A salient feature of the IPM system for $P$. strobi is the combination of tactics involving silviculture and host genetic resistance. The tactics depend on a preliminary weevil hazard rating of the area based on a determination of the potential degreeday accumulation for a site (Spittlehouse $e t$ al. 1994). In low hazard areas, silviculture-driven tactics such as mixed-species planting and increased planting density may be sufficient to produce a successful spruce crop. In high hazard areas, the silvicultural prescription could include the use of resistant stock if available.

The existence of Sitka spruce genotypes with resistance to weevil damage was first noted in British Columbia in the early 1930s (Alfaro 1982; Alfaro et al., 1995), and recently, host resistance was demonstrated in replicated trials in Sitka spruce 


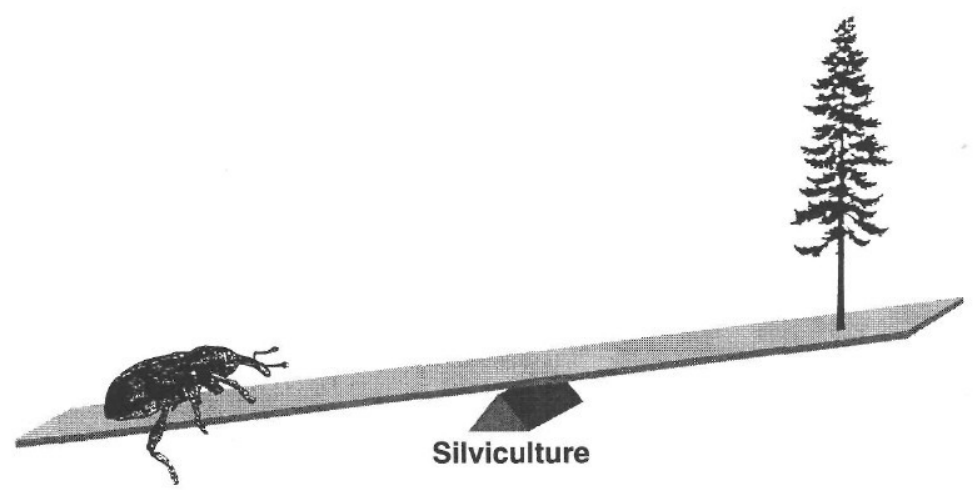

Successful Weevil Colonization

$\checkmark$ Attacks early in the spring before defenses are fully active

$\checkmark$ Feeding to de-activate resin canals

$\checkmark$ Mass attack by quickly laying

numerous eggs

$\checkmark$ Gregarious feeding by larvae

$\checkmark$ Attacks lower in the stem where

resin canal density is low
Successful Tree Defense

$\checkmark$ Variable phenology

$\checkmark$ Repellent odours

$\checkmark$ Dense bark resin canals

$\checkmark$ Traumatic resin canals

$\checkmark$ Fluid resin to inundate

galleries

$\checkmark$ Thin bark; insufficient nutrition

Fig. 4. Whether a tree is successfully colonized by the white pine weevil depends on a delicate balance between tree defenses and the strategies used by the weevil to overcome them. Silvicultural manipulations can be used to tip the balance in favour of the tree.

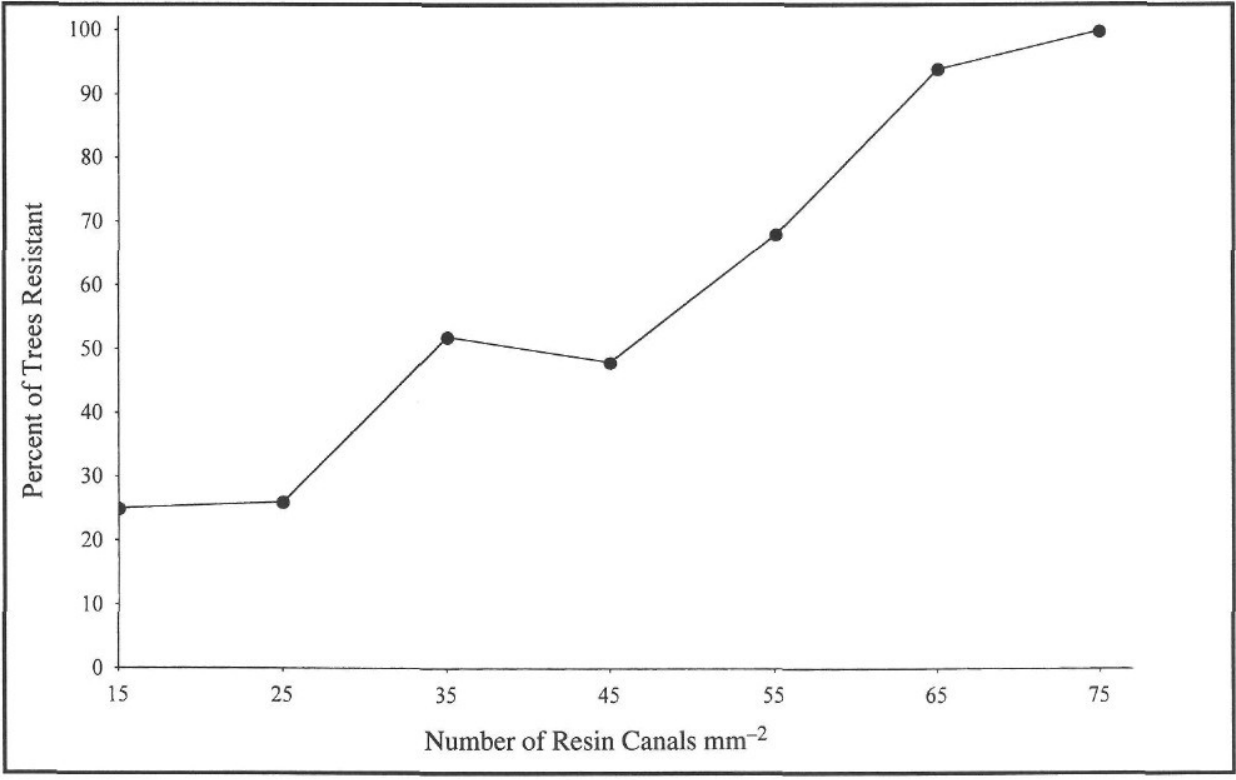

Fig. 5. The resin canals present in the bark of spruce help in its defense against the weevil. The graph shows the percentage of white spruce trees with resistance to white pine weevil among trees tabulated by density of resin canals in the bark of the uppermost lateral branches.
(Alfaro and Ying 1992; Ying 1991) and in white spruce (Alfaro et al. 1996b; Kiss and Yanchuk 1991; Kiss et al. 1994). In eastern North America, resistance of eastern white pine, Pinus strobus L., to $P$. strobi damage, was demonstrated by Wright and Gabriel (1959), Plank and Gerhold (1965), Connola (1996), and others.
Successful utilization of host resistance requires an understanding of the mechanisms used by spruce to defend against $P$. strobi, and of the strategies used by the weevil to overcome these defenses, and how these are effected by site conditions and silviculture. Optimal silvicultural systems will enhance tree defenses and reduce the possibility of weevil success. The wee- 


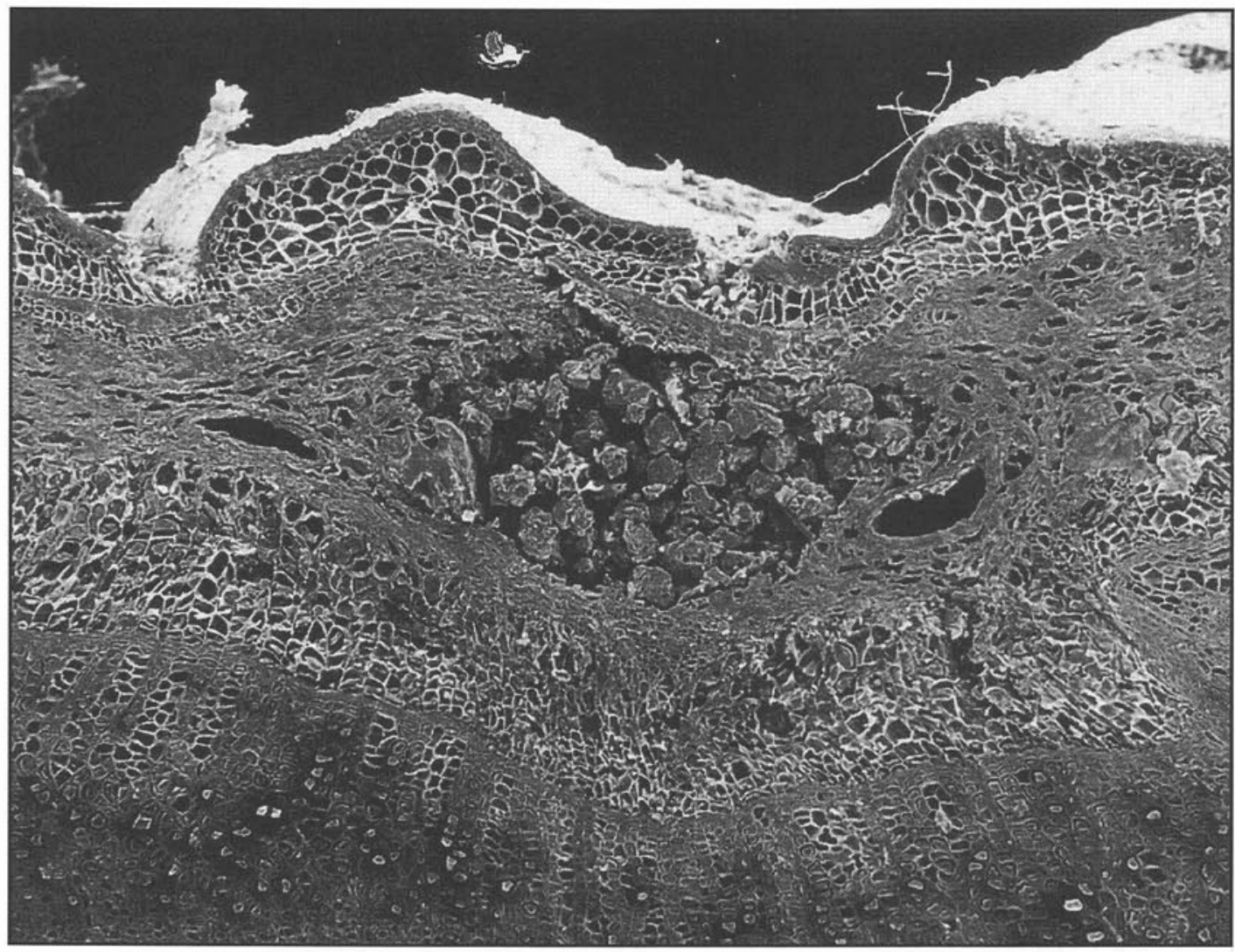

Fig. 6. One of the strategies used by $P$. strobi to overcome the tree defenses is to deactivate the bark resin canal system. This cross-section of a spruce leader shows a first instar white pine weevil larval gallery (center, filled with frass) between two collapsed bark resin canals. $P$. strobi adults and larvae avoid puncturing bark resin canals during initial feeding. Consumption of the canal's supportive tissue causes resin canal collapse and de-activation, allowing subsequent mass colonization of the leader.

vil/spruce relationship is the product of millions of years of coevolution, in which a number of defences and counter-defenses have developed (Fig. 4). These are gradually becoming apparent. Alfaro (1994) and Lewis (1995) outlined possible sources of resistance to weevil attack in spruce trees. Blockage of successful host colonization could occur at a number of places in the complex host/weevil interaction leading to a successful brood. Olfactometer and feeding bioassay studies (Alfaro and Borden 1985; Tomlin 1995; Alfaro 1996) demonstrated that odours from certain host genotypes are repellent to the weevil; thus, in some cases, blockage of host selection could occur before the weevil arrives to the leader. The resin canal system present in the bark of spruce plays a major role in the resistance to weevil attack (Santamour and Zinkel 1977; van Buijtenen and Santamour 1972). Berryman $(1972,1988)$ termed this system "constitutive resistance", describing the resistance which exists in the tree prior to infestation, such as resin ducts and other plant structures. Sitka and white spruce resistant to the white pine weevil have denser resin canals in the cortex than susceptible trees (Tomlin and Borden 1994) (Fig. 5). P. strobi avoids puncturing resin canals during adult feeding and egg-laying (Stroh and Gerhold 1965), as well as during initial larval feeding (Alfaro 1995). In addition to this constitutive resistance, spruce can turn on an inducible resistance mechanism. In response to weevil feeding and oviposition, traumatic resin canals develop from the cambium and produce resin which kills eggs and larvae (Alfaro 1995). Traumatic resin has higher ratios of monoterpenes to resin acids, hence it is more fluid than resin produced in the bark resin canals (Connor 1996). Low viscosity resin is probably more toxic to weevils than viscous resin. Sahota et al. (1994) are investigating the existence of chemicals in the bark of resistant spruce which may have negative effects on the weevil reproductive physiology.

The weevils utilize several strategies for overcoming the tree defenses. Hulme (1995) found that even the most resistant Sitka spruce clones could be successfully colonized if the attack occurred early in the season. Thus, it appears that the physiological processes that underlie the tree defenses may not be active the entire year, but they may be gradually activated in the spring. Therefore, when planting spruce, (either resistant or not) it would be advisable to utilize a mixture of genotypes from sources with different phenology. This would make more difficult the formation of weevil races with optimal host synchrony. Stock from sources with different altitude or latitude should differ in phenology.

Another weevil strategy for overcoming the tree defenses is the de-activation of the bark resin canal system. Feeding on the tissues that surround the bark resin canals prior to oviposition deprives the canals from support and nourishment and causes their collapse (Fig. 6). Mass-attack, i.e., deposition of many eggs in a short period over a given leader surface area, ensures collapse of the resin canal system over significant portions of the leader and ensures that at least some larvae will survive to adult. Working with interior spruce, Alfaro et al. (1996a) 
found that little emergence occurred if the weevil excavated fewer than 60 egg punctures (deposition of about 100 eggs) and the brood was overcome by bark and traumatic resin. Gregarious larval feeding, evident in the formation of the "feeding ring", in which the larvae move below the bark consuming the phloem in synchrony, is an effective adaptation to overcome the tree defenses. Gregoire (1985) discusses the advantages of gregarious feeding in bark beetles. We are currently working to test if, as suggested by Wallace and Sullivan (1985), the cooler conditions prevalent in shaded stands, slow down the process of egg deposition making more difficult mass-attack and feeding ring formation.

An important consideration when utilizing resistant genotypes in reforestation programs is its deployment in mixtures with susceptible stock. Using cage experiments, Alfaro (1996) found that, when confined to resistant trees, gravid females oviposited lower in the stem, below the leader, where resin canal density was reduced by the increase in stem diameter (a dilution effect). Therefore, there is a risk that, if large plantations of purely resistant genotypes are created, the weevil could adapt to attack older internodes, where resin canal density is lower. There is no difficulty in rearing this insect, under greenhouse conditions, on bolts of Sitka spruce.

Different degrees of resistance could be added to ecosystems at risk of weevil infestations. Ecosystems located in low weevil hazard zones could contain a high proportion of susceptible spruce (higher than 50\%) mixed with non-host species and still yield a reasonable amount of good quality timber. Seeds collected from naturally-resistant provenances, e.g., Big Qualicum wild seed collections for Sitka spruce (Ying 1991), would produce stock with an increased, but variable, level of resistance over that of wild seed. This variable resistance may be adequate, particularly in a silvicultural system which combines tactics that increase tree and stand resistance and reduce the likelihood of the weevil overcoming these defenses: increased plantation density, mixed species planting and shade conservation. Intensive silviculture (pruning, sanitation thinning) should be practiced to remove defective trees and concentrate growth on good-form trees. In the future, increased levels of resistance will be available from vegetative propagation of resistant trees, and from seed-orchard seed. However, the deployment of these genotypes should, at all times, take into consideration the need for avoiding the risk of insect selection leading to biotypes capable of overcoming the resistance mechanisms. Judicious use of genetic resistance, along with other measures for restoring ecosystem balance and maintenance of biodiversity, will secure continued production of spruce timber in $\mathrm{BC}$.

\section{References}

Alfaro, R.I. 1982. Fifty-year-old Sitka spruce plantations with a history of weevil attacks. J. Entomol. Soc. BC. 79: 62-65.

Alfaro, R.I. 1989. Stem defects in Sitka spruce induced by Sitka spruce weevil, Pissodes strobi (Peck.). pp 177-185. In Insects affecting reforestation: Biology and damage. R.I. Alfaro and S. Glover (Eds.). Proceedings of a IUFRO symposium held on 3-9 July 1988, in Vancouver, BC, Canada, under the auspices of the XVIII International Congress of Entomology, Forestry Canada, Victoria, BC.

Alfaro, R.I. 1992. Forecasting spruce weevil damage. pp. 10-16. In Proceedings of a Spruce weevil Symposium, T. Ebata (Ed.) held in Terrace, BC, March 12th, 1992. BC. Min. Forests, Prince Rupert Region. Special report. $42 \mathrm{p}$.
Alfaro, R.I. 1994. The white pine weevil in British Columbia: biology and damage. pp. 7-22. In The white pine weevil: Biology, damage and management. R.I. Alfaro, G. Kiss, and R. G. Fraser (Eds.). Proc. of a meeting held 19-21 January 1994, in Richmond, BC Canada. Can. For. Serv. FRDA Report No. 226, 311 p.

Alfaro, R.I. 1995. An induced defense system in white spruce to attack by the white pine weevil, Pissodes strobi Peck. Can. J. For. Res. 25: 1725-1730.

Alfaro, R.I. 1996. Feeding and oviposition preferences of the white pine weevil on resistant and susceptible Sitka spruce clones in laboratory bioassays. Environ. Entomol.

Alfaro, R.I. and J.H. Borden. 1985. Factors determining the feeding of the white pine weevil on its coastal British Columbia host, Sitka spruce. Proc. Entomol. Soc. Ont. 116(suppl.): 63-66.

Alfaro, R.I. and C.C. Ying. 1990. Levels of Sitka spruce weevil, Pissodes strobi (Peck), damage among Sitka spruce provenances and families near Sayward, British Columbia. Can. Entomol. 122: 607-615.

Alfaro, R.I. and S.A.Y. Omule. 1990. The effects of spacing on Sitka spruce weevil damage to Sitka spruce. Can. J. For. Res. 20: 179-18. Alfaro, R.I., M.A. Hulme and J.W.E. Harris. 1985. Insects associated with the Sitka spruce weevil, Pissodes strobi (Coleoptera: Curculionidae) in Sitka spruce, Picea sitchensis in British Columbia, Canada. Entomophaga 30: 415-418.

Alfaro, R.I., J.H. Borden, R.G. Fraser and A. Yanchuk. 1995. The white pine weevil in British Columbia: Basis for an integrated pest management system. For. Chron. 71: 66-73.

Alfaro, R.I., G.K. Kiss and A. Yanchuk. 1996a. Variation in the induced resin response of white spruce, Picea glauca (Moench) Voss, to attack by Pissodes strobi Peck. Can. J. For. Res. 26: 967-972.

Alfaro, R.I., F. He, G.K. Kiss, J. King and A. Yanchuk. 1996 b. Resistance of white spruce to white pine weevil: Development of a resistance index. J. For. Ecol. and Manag. 81: 51-62.

Altieri, M.A. 1994. Biodiversity and pest management in agroecosystems. NY Food Products press. $185 \mathrm{p}$.

Berryman, A.A. 1972. Resistance of conifers to invasion by barkbeetle-fungus associations. BioScience 22: 598-602.

Berryman, A.A. 1988. Towards a unified theory of plant defense. pp. 39-56. In Mechanisms of woody plant defenses against insects W.J. Mattson, J. Levieux and C. Bernard-Dagan (Eds.) Springer-Verlag, New York, NY 416 p.

Connola, D.P. 1966. Preliminary studies on resistance in Eastern white pine to the white pine weevil, Pissodes strobi (Coleoptera: Curculionidae) in New York. Ann. Entomol. Soc. Amer. 59: 1011-1012.

Connor-Antonijevic, Eva. 1996. Chemical composition of constitutive and induced resin in the leaders of interior spruce, Picea glauca ssp. Engelmannii. Independent study semester report. Simon Fraser University, Dept. Biological Sciences. Burnaby, BC. 46 p.

Cozens, R.D. 1987. Second broods of Pissodes strobi (Coleoptera: Curculionidae) in previously attacked leaders of interior spruce. J. Entomol. Soc. BC. 84: 46-49.

Gregoire, J.C. 1985. Host colonization strategies in Dendroctonus: Larval gregariousness or mass attack by adults. pp. 147-154 In The role of the host in the population dynamics of forest insects. L. Safranyik, (Ed.). Proc. IUFRO conference 4-7 Sept. 1983. Pacific Forestry Centre, Can. For. Serv., Victoria, BC.

Hulme, M. 1995. Resistance of translocated Sitka spruce to damage by Pissodes strobi related to tree phenology. J. Econ. Entomol. 88: 1525-1530.

Humble, L.M., N. Humphreys and G.A. Van Sickle. 1994. Distribution and hosts of the white pine weevil, Pissodes strobi (Peck), in Canada. pp. 68-75. In The white pine weevil: Biology, damage and management. R.I. Alfaro, G. Kiss, and R.G. Fraser (Eds.). Proc. of a meeting held 19-21 Jan. 1994, in Richmond, BC Canada. Can. For. Serv. FRDA Report No. 226, 311 p.

Kiss, G.K. and A. Yanchuk. 1991. Preliminary evaluation of genetic variation of weevil resistance in interior spruce in British Columbia. Can. J. For. Res. 21: 230-234. 
Kiss, G.K., A.D. Yanchuk and R.I. Alfaro. 1994. Recent advances in white pine weevil research in British Columbia. pp. 150-159. In The white pine weevil: Biology, damage and management. R.I. Alfaro, G. Kiss, and R.G. Fraser (Eds.). Proc. of a meeting held 19-21 Jan. 1994, in Richmond, BC Canada. Can. For. Serv. FRDA Report No. 226,311 p.

LaSalle and I.D. Gauld. 1993. Hymenoptera: Their diversity, and their impact on the diversity of other organisms. pp. 1-26. In Hymenoptera and biodiversity. J. LaSalle and I.D. Gauld. (Eds.). C.A.B. International, Oxford, U.K. 348 p.

Lewis, K.G. 1995. Genetic variation among populations of Pissodes strobi (white pine weevil) reared from Picea and Pinus hosts as inferred from RAPD markers. M.Sc. Thesis, University of BC. 227 p.

McLean, J.A. 1989. Effect of red alder overstory on the occurrence of Pissodes strobi (Peck) during the establishment of a Sitka spruce plot. pp. 167-176. In Insects affecting reforestation: Biology and damage. R.I. Alfaro and S. Glover (Eds.). Proceedings of a IUFRO symposium held on 3-9 July 1988, in Vancouver, BC, Canada, under the auspices of the XVIII International Congress of Entomology, Forestry Canada, Victoria, BC.

McLean, J.A. 1994. Silvicultural control of the white pine weevil at the UBC Malcolm Knapp Research Forest. pp. 248-253. In The white pine weevil: Biology, damage and management. R.I. Alfaro, G. Kiss and R.G. Fraser (Eds.). Proc. of a meeting held 19-21 Jan. 1994, in Richmond, BC Canada. Can. For. Serv. FRDA Report No. 226, 311 p.

McMullen, L.H. 1976. Spruce weevil damage. Ecological basis and hazard rating for Vancouver Island. Environ. Canada. For. Serv. Rep. BC-X-141.

Plank, G.H. and H.D. Gerhold. 1965. Evaluating of host resistance to the white pine weevil (Pissodes strobi) (Coleoptera: Curculionidae) using feeding preference tests. Ann. Entomol. Soc. Amer. 58: 527-532.

Sahota, T.S., J.H. Manville and E. White. 1994. Interaction between Sitka spruce weevil and its host Picea sitchensis (Bong) Carr.: A new resistance mechanism. Can. Entomol. 126: 1067-1074.

Santamour, F.S. and D.F. Zinkel. 1977. Resin acids, resin crystallization and weeviling in Balkan $\mathrm{x}$ eastem white pine hybrids. pp. 164-175 In Proc. 25th Northeastern Forest Tree Improvement Conference.
Silver, G.T. 1968. Studies on the Sitka spruce weevil, Pissodes sitchensis, in British Columbia. Can. Entomol. 100: 93-110.

Spittlehouse, B.G. Sieben and S.P. Taylor. 1994. Spruce weevil hazard mapping based on climate and ground survey data. pp. 23-32. In The white pine weevil: Biology, damage and management. R.I. Alfaro, G. Kiss, and R.G. Fraser (Eds.). Proc. of a meeting held 19-21 Jan. 1994, in Richmond BC Canada. Can. For. Serv. FRDA Report No. 226, 311 p.

Stroh, R.C. and H.D. Gerhold. 1965. Eastern white pine characteristics related to weevil feeding. Silvae Genetica. 14: 160-169.

Sullivan, C.R. 1961. The effect of weather and the physical attributes of white pine leaders on the behaviour and survival of the white pine weevil, Pissodes strobi, in mixed stands. Can. Entomol. 93: 721-741. Taylor, S.P., R.I. Alfaro, C. Delong and L. Rankin. 1996. The effects of overstory shading on white pine weevil damage to white spruce and its effects on spruce growth rates. Can. J. For. Res. 26: 306-312.

Tomlin, E. 1995. Mechanisms of resistance of Sitka spruce to white pine weevil. $\mathrm{PhD}$ Thesis, Simon Fraser University.

Tomlin, E. and J.H. Borden. 1994. Development of a multicomponent resistance index for Sitka spruce resistant to the white pine weevil. pp. 117-133. In The white pine weevil: Biology, damage and management. R.I. Alfaro, G. Kiss, and R.G. Fraser (Eds.). Proc. of a meeting held 19-21 Jan. 1994, in Richmond, BC, Canada. Can. For. Serv. FRDA Report No. 226, 311 p.

van Buijtenen, J.P. and F.S. Santamour Jr. 1972. Resin crystallization related to weevil resistance in white pine (Pinus strobus). Can. Entomol. 104: 215-219.

Wallace, D.R. and C.R. Sullivan. 1985. The white pine weevil, Pissodes strobi (Coleoptera: Curculionidae): a review emphasizing behaviour and development in relation to physical factors. Proc. Entomol. Soc. Ont. 16(Suppl.): 39-62.

Wright, J.W. and W.J. Gabriel. 1959. Possibilities of breeding weevil resistant white pine strains. USDA For. Serv. Sta. Pap. Northeast For. Exp. Stn. No. 115, 35.

Ying, C.C. 1991. Genetic resistance to the white pine weevil in Sitka spruce, BC Ministry of Forests Res. Note No. 106. Victoria, BC Canada. 